\title{
USE OF INDUSTRIAL LAND IN AL-MAHMODIYA DISTRICT
}

\author{
Zamil L. Timman \\ Lecturer doctor in Ministry of Education-Managing Director of Baghdad Education-Al-Rusafa/1/Branch of studies, \\ Iraq. \\ Email: aalaatad@yahoo.com
}

Article History: Received on $19^{\text {th }}$ July 2021, Revised on $29^{\text {th }}$ July 2021, Published on $11^{\text {th }}$ August 2021

\section{Abstract}

Purpose of the study: The research aims to examine the impact of factors related to the spatial distribution of industries and determine their importance in controlling the economic activity of Mahmoudiyah City to determine the direction of the industry compass on the level of this district. There are different industry types in this city, including hand or small industry, such as spinning, knitting, and fancywork industry. As well as light industry, for example, woven, cane, building materials, wooden and metallic industry.

Methodology: This research is of theoretical type, and the research method is descriptive-analytical, and the method of data collection is a library and has been done by referring to documents, books, and articles.

Results: The results showed that more of these industries mentioned above are found in Al-mahmodiya center and Allatefiya because found labor market and its nearly of consumed as well as increase of population with different skills hands lead to the stable economic and social case. There is a challenge in the provided modern machine and discontinue of electric current, leading to decreased production.

Application: This study can be useful in the Studies of Industrial Geography.

Novelty: This field study indicates that the industrial craft is affected by choosing the suitable place for industrial plants to reduce the pollution and noise ratio in the known industrial regions and describes one of the major problems that still exists is the return of land ownership.

Keywords: Use of Industrial Land, Baghdad, Types of Industry, Mahmoudiyah City, Land Ownership.

\section{INTRODUCTION}

The industry is one of the civilizational features that measure the progress of peoples and promote the process of economic and social development to develop the life of society. An industry - or sector - is the whole of all economic activities by companies, people, and organizations involved in the production of goods and services for a particular field. Industries are usually categorized by the goods and services they produce (Industry, n.d.). Industrial crafts are an important indicator of the development of the industrial side in our beloved country. The development of the industry is linked to the global scientific and technological development of various types of industry, which is linked to the growth of the economies of the countries. Industrial land use means land used for commercial establishments, manufacturing plants, public utilities, mining, distribution of goods or services, administration of business activities, research and development facilities, warehousing, shipping, transporting, remanufacturing, stockpiling of raw materials, storage, repair and maintenance of commercial machinery or equipment, and waste management (Industrial land use definition, n.d.).

Our beloved country has a wide variety of industries that are closely linked to its history and present. The main industries in Iraq in the past and present (textile industries, pottery industry, wood industry, wicker industry, construction materials industry, food production, as well as other types of industries) are among the most prominent industries in the world. These industries are remarkably prevalent in the districts of Mahmoudiya City, which necessitated a geographical analysis of the distribution of these industries and the means to promote and develop them to meet the needs of the citizen and increase the city's economic stability.

Mahmoudiyah, also transliterated Al-Mahmudiyah, Al-Mahmoudi, or Al-Mahmudiya, prefixed usually with Al- is a rural city south of Baghdad known as the "Gateway to Baghdad." The city's proximity to Baghdad made it central to the counterinsurgency campaign. The geographical location of the city of Mahmudiyah is on the southern side of Baghdad Governorate, with an area of $(567 \mathrm{~km} 2)$. Al-Mahmodiyah district in good geographical plain land near Baghdad center and provided with transport devices. This city contains fertile soil and a suitable climate for agriculture that irrigates by the Euphrates River's water. There are different industry types in this city, including hand or small industry, such as spinning, knitting, and fancywork industry. As well as light industry, for example, woven, cane, building materials, wooden and metallic industry.

\section{Research Objectives}

The objectives of this study are to examine the impact of factors related to the spatial distribution of industries and determine their importance in controlling the economic activity of Mahmoudiyah City and determine the direction of the industry compass on the level of this district. 


\section{Research Questions}

1-What are the geographical determinants of the various industries around the city of Al- Mahmoudiyah?

2-How can they be expanded and introduced in the future to large factories associated with the local economy in general?

\section{Research Hypothesis}

The geography of Mahmoudiyah cities south of Baghdad is a clear economic and social influence in its industrial development and spatial identification. This is further enhanced by the accumulated experience of the industrial handicrafts in the study area (district aspects).

\section{METHODOLOGY}

This research is of theoretical type, and the research method is descriptive-analytical. The data collection method is a library and has been done by referring to documents, books, and articles. The sample research was randomly collected from the total various industrial uses of the Mahmoudiyah suburbs by approximately (1293) workshops during the field study of the studied sample. Information approved by official government agencies was used between 2013 and 2016. The sample search includes the district center, Latifiya, Youssifiyah, as well as the Rasheed Area. The search method followed a descriptive approach as well as the field side data.

\section{RESULTS AND DISCUSSION}

\section{Geographical description of the study area}

The study area is geographically located in the capital Baghdad. It includes residential districts (district Center, AlNuman District, Al-Husseinya District, Al-Moazefein District, Al-Sarai District, Al-Jadida District, Al-Askari District, Al-Mortaza District, and Al-Jaziraa District) as well as other areas mentioned in the sample search, prescribed industrial activities as the voltage which the worker causes to produce food, textile, metal, wooden used where human labor is more than the mechanical action, indicating the existence of a craft or profession. The study area consisted of a total area of up to $567 \mathrm{~km} 2$, as shown in (Table 1) a (Map 1) and (Map 2).

Table 1: Distribution of the study area $\left(\mathrm{km}^{2}\right)$

\begin{tabular}{llcl}
\hline & $\begin{array}{c}\text { Areas of } \\
\text { Mahmudiyah } \\
\text { district }\end{array}$ & Area $\mathbf{~ k m ~}^{\mathbf{2}}$ ) & \multicolumn{1}{c}{ residential districts } \\
\hline 1 & $\begin{array}{l}\text { Mahmoudiya district } \\
\text { center }\end{array}$ & 32 & $\begin{array}{l}\text { It includes Al-Numan, Zahraa Complex, Al Hussainiya, Al Jadida, Al } \\
\text { Serail, Al Salam, and Al Askari District }\end{array}$ \\
\hline 2 & Latifiya & 147 & $\begin{array}{l}\text { It includes the district center, Al Mazraa district, Al Zuhour district, and } \\
\text { Al-Askari district }\end{array}$ \\
\hline 3 & Yusufiya & 180 & $\begin{array}{l}\text { It includes the district center, Al moalemeen district, the east Al Jawan } \\
\text { district, Al-Radwaniyah }\end{array}$ \\
\hline 4 & Al - Rasheed & 208 & Includes Al-Rasheed Industrial Area (Aweerij) \\
\hline $567 \mathrm{~km} 2$ & & \\
\hline
\end{tabular}

Source: The 1/50,000-scale baseline map for the Baghdad secretariat.

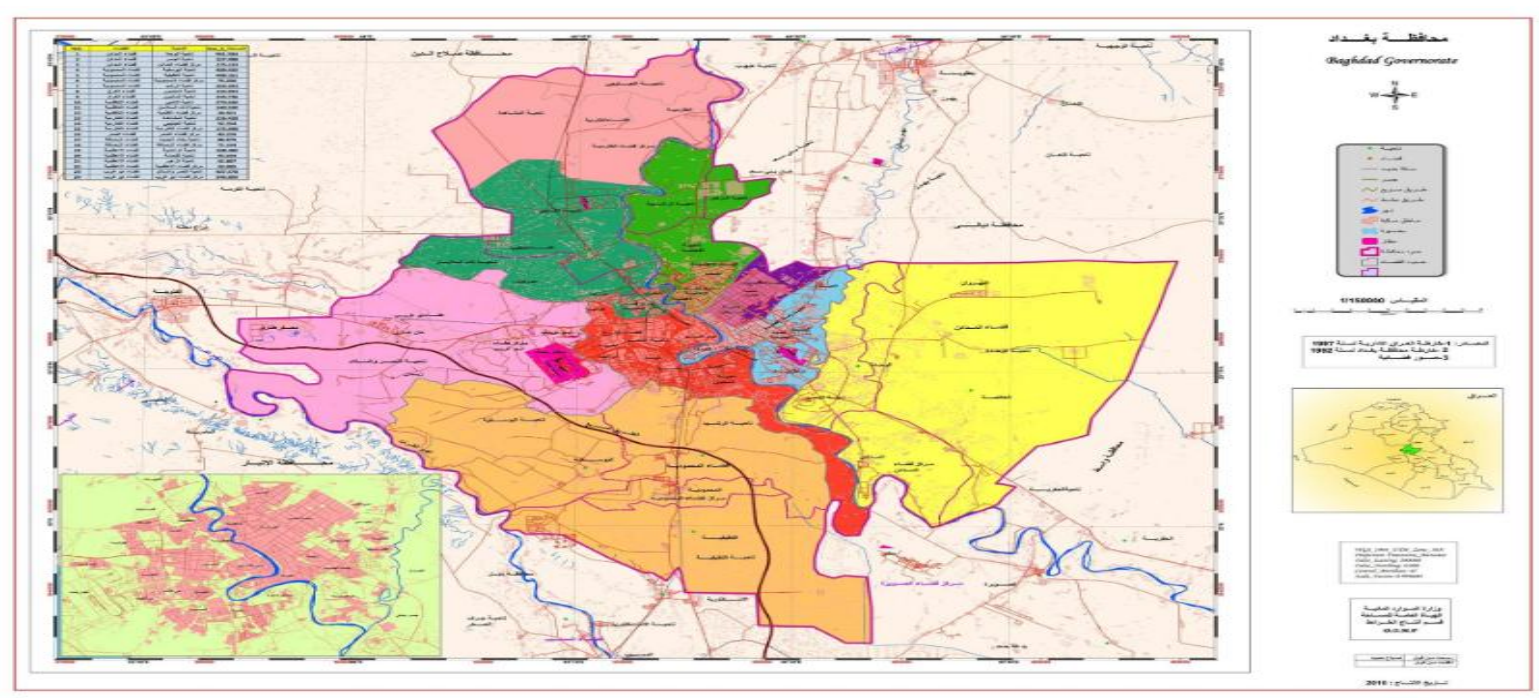

Figure 1: Geographical location of the study area relative to the capital Baghdad 
Source: The Republic of Iraq, Ministry of Water Resources, General Commission for Survey, Maps Department, Baghdad, 2018.

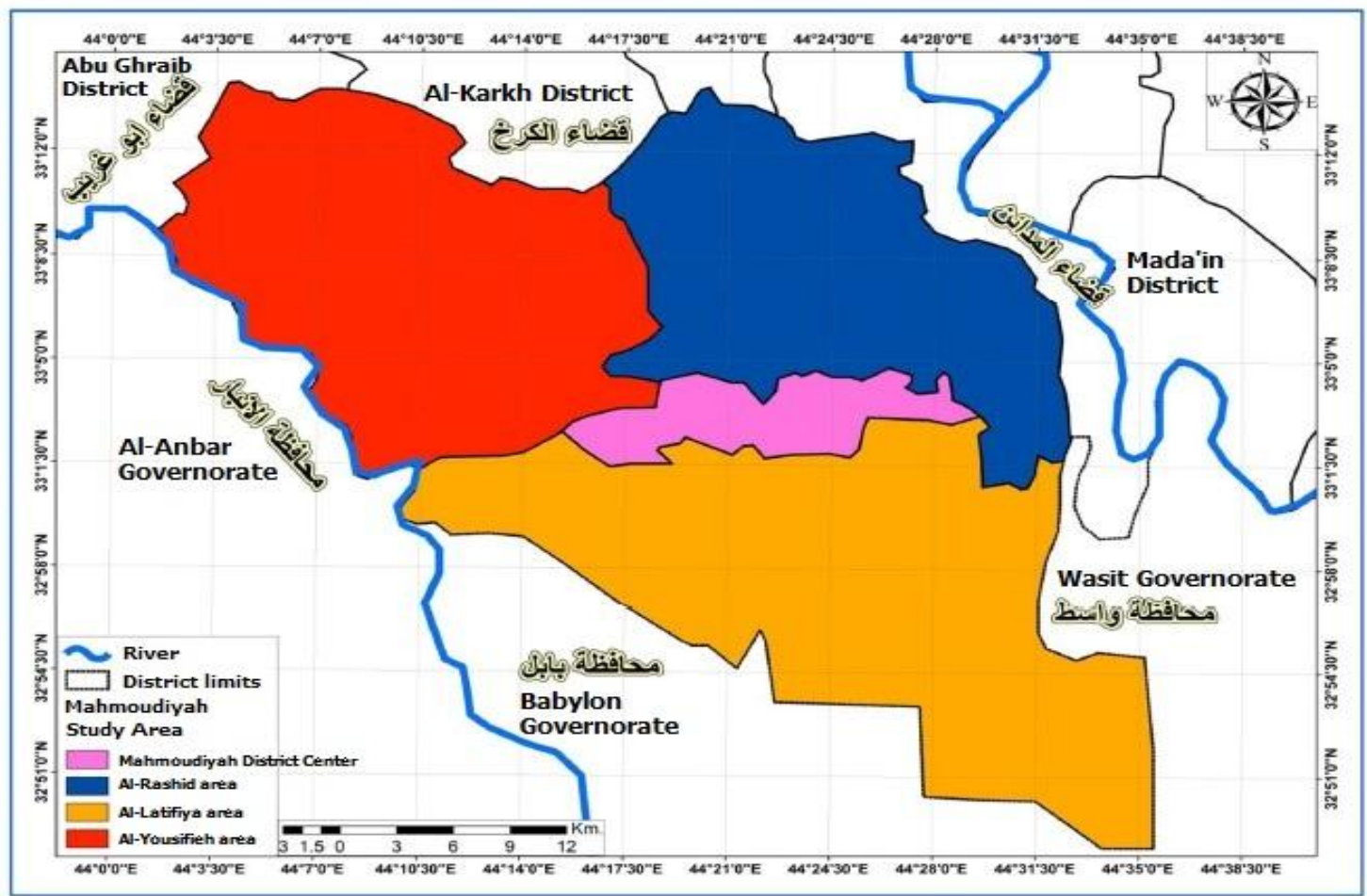

Figure 2: Administrative distribution of the geography of Mahmoudiya cities

Source: The Republic of Iraq, Ministry of Water Resources, General Commission for Survey, Maps Department, Baghdad, 2018.

\section{The concept of industrial activity}

The Mahmudiyah district center is characterized by its heritage and history, which has encouraged the establishment of a different collection of industrial crafts that characterize the inhabitants of these areas. Industrial craft can be defined as that which man practices and makes a living. The geographical environment of the Mahmudiyah district contributes to the diversity of industries in which they meet the needs of their inhabitants from different living requirements, depending on the activity of the human being (Sharif, 1976) and (Hammoudi, 1997).

\section{Classification of industrial crafts}

The system of craftsmen is one of the oldest industrial systems known to our human society during the Middle Ages, which classifies the industrial professions by relying on their products of different commodities depending on the different functional specialization of the population, leading to a great industrial diversity in these regions (Al-Sheikhly, 1974) and (Al-Hasan, 1986).

The Industrial Revolution in our modern society has contributed to the evolution and diversity of industries and the development of new concepts of industrial crafts that are more complex in concept. Includes the concept of industry in America (manufacturing industries) for its high value to meet human demands.

In Iraq, law No. 22 was enacted in 1973, which described small industries as an activity leading to the production of a commodity for final, intermediate, or investment consumption using various raw materials. On this basis, crafts industrially in Iraq were classified into two main groups (Al-Barazi, 1986) and (Sharif, 1981) and (Jassem, 1986) and (Hajji, 1994), as shown in (Table 2), namely:

1. The handicrafts that have the advantage of producing different commodities are skillfully developed by their farmers, such as Hand-held spinning, embroidery, hand-knitting, wooden sculpture, clay toys, photography, sculpture, and other industries.

2. The second group, which includes light or small industries, is classified into several classifications or sections:

A- Textile industries (manufacturing textiles and fabrics) include producing yarn, cotton, silk weaving, washing and pressing fleeces, printing fabrics, and various types of sewing.

B- Industries of reeds and fronds include making mats using reeds, reed barriers, as well as baskets, dishes, and other industries. 
C- Building materials industries use raw materials for the purpose of producing materials for use in building construction, for example, bricks, gypsum , and gravel, the manufacture of various pottery, in addition to quarries and crushing stones.

D- Metallurgical industries include different types: blacksmithing and welding, smelting and plumbing, plumbing and Tinning products, repair workshops, turning and cooling, machete making, metal furniture, as well as other simple electrics works.

E- The group of food industries involved in the production of various foodstuffs such as vegetable oil extraction, molasses, dairy products, vinegar and Tarshi, grain grinding, ice, tomato paste, salt purification, and filling, rose water extraction, perfume, and other food industries.

F- Various leather industries include tanning and leather, shoe industry, various leather products, slaughterhouses, and others.

Table 2: Main types of Industrial Activity within Study Sample

\begin{tabular}{lll}
\hline & Manual Industrial Activity & Light industrial crafts \\
\hline 1 & producing yarn & manufacturing textiles and fabrics \\
\hline 2 & Embroidery & Industries of reeds and fronds \\
\hline 3 & Manual knitting & Building materials industries \\
\hline 4 & clay toys & Wood Industries \\
\hline 5 & wooden sculpture & Metallurgical industries \\
\hline 6 & Baskets and hand fan & leather industries \\
\hline 7 & Photography and music machine making & food industries \\
\hline
\end{tabular}

Source: Author

\section{Types and characteristics of industrial activity in the study sample}

1. The food craft: The existing food craft in the city of Mahmoudiya varies to meet the needs of the inhabitants of these areas, such as the craft of bread and the samoon (Baguette), the craft of making pastries and desserts, and the craft of making milk. The main focus is on bread craft, a basic food rich in starch and carbohydrates necessary for the human body. The study area is also characterized by the manufacture of unique and distinctive kinds of pastries and sweets such as zulbia and baklava, in addition to the agricultural nature of the districts of Mahmudiyah, which helps increase the production of milk and its derivatives and market (Al-Sharbti, 1967; Jaber, 1981); Hassan, 2002); Al-Baghdadia, 1966).

2. Textiles and woolens: It is a historical craft linked to the age of the Rafidain Valley civilization and inherited over generations such as the craft of the paper industry, tailoring craft, embroidery, and others (Al-Durra, 1975; $\mathrm{Al}-$ Samarrai, 1997; Abdul-Latif, 2000; Al-Nafsy, 2001).

3. Wood Craft \& Products: Wood is an important material that goes into furniture, carpentry, and more. The wood trade plays a role in the construction of large buildings or the construction of tents of mayors, stadas (Saree, 1923).

4. Book-binding craft: Writing has evolved very markedly, calling for a cover or binding that decorates and maintains this important book for long periods through which it travels through generations after many books have been destroyed by fire or by loss. Book packaging first emerged in Coptic houses of worship in Egypt. After going through various industrial stages using ivory, gold, and silver plates and embroidered cloth spread all over the world (Al-Qusairi, 1979; Awad, 1986 and Raouf, 1982).

5. The craft of the construction products industry includes the manufacture of construction materials such as tile, cutting-edge tools, as well as the manufacture of metal furniture of various types (chairs, tables, etc.). The study area is also known for the poultry incubators industry, in line with the needs of some residents of these areas (Al-Kayyali, 1972).

\section{Variables affecting industrial settlement in Mahmoudiya}

Industrial settlement in the study sample is influenced by a variety of variables where the emergence of an industry in a region is related to variables that control the availability of appropriate conditions for the diversity of the industrial craft and encourage their establishment in certain regions according to the conditions of those regions (Kendrew, 1976). these variables can be summarized as follows:

Natural variables include geospatial, surface, climate, soil, and water). The geographical location of Mahmudiyah's district has a major impact on its economic and industrial activity, with an important group of textile factories, such as the General Company for the manufacture of Clothing. Mahmudiyah district represents the southern gateway to the capital Baghdad, and the diversity of transport means that it connects to the center of the capital, Baghdad, which

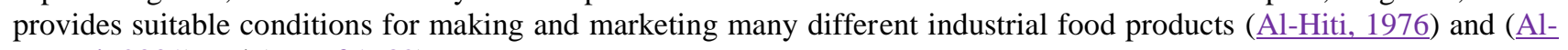
Kanani, 2001) and (Raouf,1982). 
The study area is a plain area, which is considered a sedimentary plains land that descends east flat, and whose land is based on the Euphrates River water, the quality of fertile soil with physical and chemical characteristics suitable for agriculture, encouraging the concentration of populations in those areas. These conditions help produce diverse crops such as maize crops, which encourages increased production of food and textile industries (Fadil, 2000) and ( $\underline{\text { Habib, }}$ 1981).

The geography of the study area represents an attraction for many different industries and its proximity to the major markets of the capital with all means of transport. The Mahmoudiya district has all the raw materials for the creation of the industrial craft; the food is for its agricultural nature and the variety of its agricultural crops used in the Oil industry, textile industry, and others. The specific economic variables for the diversity of the industrial crafts in the study area are the growing population and the diversity of their activities, which are considered to expand the industrial character as a producer and consumer to meet their living needs. The availability of capital and mobility of the population encourages the operation of plants and the expansion of energy sources, thus increasing industrial production to improve the population's economic situation (Al-Janabi, 2001).

\section{CONCLUSION}

Industrial activity of all kinds (food, textile, construction, leather, and building materials industries) is concentrated in the study area in the district center and the Rasheed and Latifiya districts compared to other regions in order to provide all the requirements for the success of the production, such as the labor market that meets the needs of consumers and its proximity to the consumer and the housing of the owners of those factories It leads to a kind of economic and social stability for the occupants of these industrial crafts. There are many obstacles that have contributed to reducing production, most notably the introduction of machines and the failure to import their original raw materials and the instability of the electric current, and the problem of ownership of industrial land. Production can be improved in quantity and quality by supporting local products, supporting economic factories by the state, and facilitating investment procedures according to systematic scientific plans as needed by the state.

\section{SUGGESTION}

Increasing production also requires the provision of original raw materials and the renewal of the quality of the working machines, as well as the continuation of regular and continuous processing of electric current, which reduces the cost of the price of the local product and makes it a strong competitor to the imported product. It must be organized in an appropriate manner that does not affect the local product and thus encourages the owners of the factories to operate their plants and have maximum power to increase production.

\section{LIMITATION AND STUDY FORWARD}

This study is limited to only Al-Mahmodiya District. It may be useful to do the same research about other countries.

\section{ACKNOWLEDGEMENT}

I wish to extend my special thanks to the libraries and government agencies (the Republic of Iraq, Ministry of Water Resources, General Commission for Survey, Maps Department, Baghdad) for providing the required data for the successful completion of this study.

\section{REFERENCES}

1. Abdul-Latif, M. (2000). Wooden Industries and their Products in the City of Baghdad. Master Thesis, Ibn Rushd College of Education, University of Baghdad (pp. 8-16).

2. Al-Baghdadia, J. A. (1966). Magazine issued by the Ministry of Culture and Guidance, Republic of Iraq. Republic House, Baghdad (pp. 170-178).

3. Al-Durra, S. (1975). Industrial Development in Iraq, the Private Sector. Al-Nujoom Printing House, Baghdad (p. 81).

4. Al-Hasan, I. M. (1986). Industrial Sociology, College of Arts. Baghdad University Printing House (pp. 41-54).

5. Al-Hiti, S. F. H. (1976). The Evolution of the Residential Function of Greater Baghdad 1950-1970 (First Edition). Dar Al-Salam House of Printing, Baghdad (pp. 16-33).

6. Al-Janabi, Z. (2001). The Role of Transportation in Determining the Locations of the Cement Industry, Plan and Development. Center for Urban and Regional Planning (pp. 65-78).

7. Al-Kanani, N. (2001). Land Uses in Al-Kadhimiya City. Master Thesis, College of Education for Girls, University of Baghdad (pp. 45-57).

8. Al-Kayyali, W. (1972). The Political Encyclopedia, Beirut. The Arab Foundation for Studies and Publishing, 1st Edition (pp. 81-88).

9. Al-Nafsy, M. A.(2001). Environment and the Future in the Light of the New World Order, Al-Qadisiyah University. Environment Unit, Environment Publications Series, 15-28.

10. Al-Qusairi, I. (1979). The Book of Binding for Muslims, the Republic of Iraq, Ministry of Culture. The Alat Institution for Antiquities and Heritage (pp. 4-12).

11. Al-Samarrai, R. (1997). Handicrafts in Iraq. Dar Alhourya House for Printing, Baghdad (pp. 11-18). 
12. Al-Sharbti, H. K. (1967). Al-Turath Al-Shaabi Magazine No. 7. Dar Alhourya Printing House, Baghdad (pp. 4156).

13. Al-Sheikhly, S. (1974). The Islamic Varieties of the Abbasid Era, Their Origins and Development. MA Thesis, University of Baghdad (pp. 42-49).

14. Awad, M. (1986). Bright Pictures of Baghdad Civilization in the Abbasid Era. Ministry of Culture, House of General Cultural Affairs, Baghdad (pp. 34-40).

15. Fadil, K. (2000). Studies in Industrial Geography. Higher Education printing house, Baghdad (pp. 37-46).

16. Habib, A. (1981). Naaman Dahsh, Geography of Industry. Dar Al Kutub for Printing and Publishing, Baghdad (pp. 64-73).

17. Hajji, A. (1994). Estimating the Factors Affecting Labor Productivity for Small Industries in Iraq. Al-Rafidain Magazine (p. 269).

18. Hammoudi, B. (1997). Al-Turath Al-Shaabi, No. 1. Republic of Iraq, Baghdad (pp. 7-16).

19. Hassan, N. (2002). Food Industries in Karbala. Master Thesis, College of Education, Al-Mustansiriya University (pp. 10-22).

20. Industrial land use definition (n.d.). Law insider. Retrieved from https://www.lawinsider.com/dictionary/in dustrial-land-use

21. Industry (n.d.). CFI. Retrieved from https://corporatefinanceinstitute.com/resources/knowledge/econ omics/industry/

22. Jaber, W. S. (1981). A study to stabilize the quality of raw materials and assistance and manufacturing methods to improve Iraqi bread production (Al-Samun). Master Thesis, College of Agriculture, University of Baghdad (pp. 13-20).

23. Jassem, T. (1986). The Socio-Economic Importance of Rural Industries in Integrated Rural Development Planning. Master Thesis, Center for Urban and Regional Planning, University of Baghdad (pp. 28-37).

24. Kendrew, W. (1976). Climate of the Continents, Arabization of Professors Hassan Taha Al-Najm and Ali AlMayah and Hassan Al-Khayyat, Part 1. Government Printing House, Baghdad (pp. 358-367).

25. Khalil al-Barazi, N. (1967). Industry and Industrial Projects in Iraq. Institute for Arab Studies and Research, Arab League (pp. 40-47).

26. Muzal, F. (1984). Factors Affecting the Selection of Industrial Projects in Iraq. Baghdad (pp.10-17).

27. Raouf, A. (1982). On Some Working Means in Industry, Ministry of Culture and Information. Directorate of Local Administration Printing House, Baghdad (pp. 11-22).

28. Saree, D. (1923). Islamic book bindings. Berlin (pp. 18-29).

29. Sharif, I. (1976). Geography of Industry. Dar Al Risalah for Printing, Baghdad (pp. 2-13).

30. Sharif, I. (1981). Geography of Industry. Ministry of Higher Education and Scientific Research, Baghdad (pp.12-13). 